\title{
MENATA PENDIDIKAN ISLAM DI INDONESIA (Sebuah Upaya Menuju Pendidikan yang Memberdayakan)
}

\author{
Sulaiman Ibrahim
}

IAIN Sultan Amai Gorontalo, Jl. Gelatik 1 Gorontalo E-mail: emand_99@hotmail.com

\begin{abstract}
Abstrak: Dalam era reformasi, pendidikan Islam menghadapi dua masalah: tuntutan kebutuhan masyarakat Indonesia terhadap kualitas pendidikan Islam dan ketidakrelevanan pendidikan Islam dengan tuntutan pembangunan masyarakat. Di samping itu, kemampuan bangsa Indonesia dalam mengelola pendidikan Islam masih rendah, sehingga pendidikan Islam tidak memiliki visi dan misi yang jelas. Sejalan dengan masalah pendidikan nasional yang sedang menghadapi era globalisasi, era dunia yang sangat terbuka. Dalam konteks ini, bangsa Indonesia harus membangun kemampuan yang memadai dalam rangka kerjasama dan kompetisi dengan negara lain. Dengan kerjasama dan kompetisi, bangsa Indonesia akan mampu meningkatkan kualitas manusia Indonesia.
\end{abstract}

Abstract: In the era of reformation, the Islamic education faces two problems: the demand of Indonesian community on the quality of Islamic education and the education irrelevance to community development. In addition, the ability of Indonesian nation in managing Islamic education is still not adequate so that Islamic educaion has no clear vision and missions. In line with the national education problems facing the globalization era, the very open world era. In this regard, the Indonesia nation must establish an adequate ability in the framework of cooperation and competition with other nations. Through cooperation and competition, the Indoesnia nastion will be able to enhance the quality of Indonesia people.

Kata Kunci: pendidikan Islam, pendidikan yang memberdayakan, Total Quality Management (TQM) 


\section{PENDAHULUAN}

Berbicara seputar pendidikan Islam, berarti membuka suatu persoalan yang mempunyai ranah demikian luas. Pembicaraannya bisa mengambil ranah filosofis, institusi serta perkembangannya dalam konteks sosio-historis, politis, dan kultural. Ini semua mencerminkan bahwa pendidikan Islam merupakan topik klasik, tapi sekaligus aktual untuk terus diperbincangkan. Apalagi, pendidikan sebagai aktivitas pengajaran yang berlangsung di mana pun dan kapan pun serta mempunyai kedudukan yang sangat sentral dalam kehidupan manusia.

Islam termasuk salah satu agama yang sangat menekankan dan mengapresiasi tinggi terhadap pendidikan. Dalam al-Qur'an banyak sekali ayat yang secara langsung maupun tidak langsung berbicara tentang pendidikan. Wahyu yang diturunkan pertama pada Nabi saw. adalah Q.S. al-'Alaq (96): 1-5, penuh muatan pendidikan yang sangat mendasar. Dalam surat ini tampak jelas, tegas, dan lugas perintah membawa (iqra) dari Allah kepada Nabi. Membaca secara harfiah maupun maknawiyah merupakan aktivitas pendidikan yang sangat penting. Sementara itu, dalam diri Nabi sendiri memberikan keteladanan yang demikian agung dalam pendidikan. Nabi saw. dikenal sebagai manusia yang tak pernah henti melakukan perenungan terhadap situasi kemanusiaan yang dijumpainya. Dalam diri Nabi juga terkandung nilai-nilai luhur dalam akhlak. Penting juga dikemukakan bahwa Nabi merupakan contoh manusia yang mengalami proses pendidikan dalam pengertian yang seluas-luasnya yaitu belajar di sekolah tanpa dinding (school without wall). ${ }^{1}$

Setiap kegiatan pendidikan perlu melaksanakan langkahlangkah strategis yang diorientasikan kepada formulasi visi dan misi dalam usaha untuk mencapai tujuan dan harapan secara efektif dan efisien bagi setiap organisasi, departemen, madrasah,

${ }^{1}$ Republika, Rabu, 17 Maret 2004. 
dan lain sebagainya. Ahmad Sutarmadi mengemukakan pendapat seorang filosof terkenal, bahwa kekuatan terbesar yang dapat membawa kemajuan dalam kehidupan manusia, adalah keinginan dan harapan yang sangat besar yang hidup dan dimiliki oleh masyarakat. Mereka menyadari, bahwa tidak ada satupun yang dapat menghalangi gelombang besar yang berupa idiologi yang hidup dalam masyarakat, idiologi itulah visi. Dengan visi yang tepat, suatu organisasi dapat bergerak maju menuju masa depan yang gemilang, dan gerakan tersebut menyebabkan organisasi itu berkembang, dan perkembangan itu akan membuat organisasi berproses mendapatkan jati dirinya dan memiliki pendukung fanatik. ${ }^{2}$ Pernyataan diatas memberikan arti betapa pentingnya visi serta misi dalam sebuah organisasi.

Permasalahan pendidikan di Indonesia secara umum, di identifikasi ke dalam empat masalah pokok, yaitu menyangkut masalah: kualitas, relevansi, elitisme, dan manajemen. Berbagai indikator kuantitatif dikemukakan berkenaan dengan keempat masalah di atas, antara lain analisis komparatif yang membandingkan situasi pendidikan antara negara di kawasan Asia. Keempat masalah tersebut merupakan masalah besar, mendasar, dan multidimensional, sehingga sulit dicari ujung pangkal pemecahannya. ${ }^{3}$ Permasalahan ini terjadi pada pendidikan secara umum di Indonesia, termasuk pendidikan Islam yang dinilai justru lebih besar problematikanya.

Pendidikan merupakan kegiatan yang bersifat sosial kemasyarakatan. Keadaannya selalu berbeda-beda sesuai dengan perbedaan corak, sifat dan kebudayaan yang berkembang di

${ }^{2}$ A. Sutarmadi, Visi dan Misi dan Langkah Strategis Pengurus DMI dan Pengelola Masjid (Jakarta: Logos, 2002), h. 3.

${ }^{3}$ Tilaar, H.A.R., Pendidikan, Kebudayaan, dan Masyarakat Madani Indonesia, Strategi Reformasi Pendidikan Nasional (Bandung: Remaja Rosdakarya, 1999), h. 76. 
masyarakat tersebut, ${ }^{4}$ atas dasar ini, disepakati oleh seluruh aliran filsafat pendidikan bahwa sistem serta tujuan pendidikan bagi suatu masyarakat atau negara tidak dapat diimpor atau di ekspor dari atau ke suatu negara atau masyarakat. Ia harus timbul dalam masyarakat itu sendiri. Ia adalah pakaian yang harus diukur dan dijahit sesuai dengan bentuk dan ukuran pemakainya berdasarkan identitas, pandangan hidup serta nilai-nilai yang terdapat dalam masyarakat atau negara tersebut. ${ }^{5}$

\section{Pendidikan Islam}

Pendidikan Islam mengandung arti yang luas, karena tidak hanya menyangkut pendidikan dalam arti pengetahuan, namun juga pendidikan dalam arti kepribadian. Pendidikan dalam arti pengetahuan tidak akan ada artinya kalau tidak melibatkan pendidikan kepribadian, karena pendidikan agama tidak cukup diukur pada ranah kognetif semata, namun juga melibatkan ranah apektif dan psikomotorik. Pendidikan Agama Islam justru diharapkan mampu merasuk ke dalam penghayatan, sehingga sikap dan tingkah laku sipenganut agama akan sejalan dengan pengetahuan keagamaan yang dimilikinya.

Pendidikan kita dalam era reformasi menghadapi dua tuntutan sekaligus. Pertama, tuntutan masyarakat terhadap mutu pendidikan kita yang rendah, dan kedua belum relevannya pendidikan dengan tuntutan perkembangan masyarakat. Sejalan dengan itu pendidikan nasional menghadapi masalah memasuki era globalisasi yaitu era dunia terbuka. Di dalam kaitan ini, kemampuan bangsa kita masih belum memadai di dalam rangka kerja sama dan juga persaingan dengan bangsa-bangsa yang lain. Kedua masalah ini, sekaligus harus dapat diatasi dalam rangka untuk meningkatkan kualitas manusia Indonesia.

\footnotetext{
${ }^{4}$ Lihat Abū Khalīl Abū al-'Ainain, Falsafah al-Tarbiyyah al-Islāmiyah fī alQur'ān al-Karīm (t.t: Dār al-Fikr al-'Arabī, 1980), h. 15.

${ }^{5}$ M. Quraish Shihab, Membumikan al-Qur'an, Fungsi dan Peran Wahyu dalam Kehidupan Masyarakat (Bandung: Mizan, 1992), h. 175.
} 
Zarkowi Soejoeti dalam makalahnya tentang "Model-model Perguruan Tinggi Islam" sebagaimana yang dikutip oleh A. Malik Fadjar mengemukakan bahwa pendidikan Islam paling tidak mempunyai tiga pengertian. Pertama, lembaga pendidikan Islam itu pendirian dan penyelenggaraannya didorong oleh hasrat mengejawantahkan nilai-nilai Islam yang tercermin dalam nama lembaga pendidikan itu dan kegiatan-kegiatan yang diselenggarakan. Dalam pengertian ini, Islam dilihat sebagai sumber nilai yang harus diwujudkan dalam kehidupan lembaga pendidikan yang bersangkutan. Kedua, lembaga pendidikan yang memberikan perhatian dan menyelenggarakan kajian tentang Islam yang tercermin dalam program kajian sebagai ilmu dan diperlakukan sebagai ilmu-ilmu lain yang menjadi program kajian lembaga pendidikan Islam yang bersangkutan. Ketiga, mengandung dua pengertian di atas dalam arti lembaga tersebut memperlakukan Islam sebagai sumber nilai bagi sikap dan tingkah laku yang harus tercermin dalam penyelenggaraannya maupun sebagai bidang kajian yang tercermin dalam program kajiannya. ${ }^{6}$

Konsep pendidikan Islam sebagaimana dikemukakan oleh Zarkowi Soejoeti tersebut, walaupun belum cukup memadai secara falsafi untuk disebut sebagai pendidikan Islam, tetapi dapat dijadikan sebagai pengantar dalam memahami pendidikan Islam secara lebih mendasar.?

${ }^{6}$ A. Malik, Fadjar, Reorientasi Pendidikan Islam (Jakarta: Fajar Dunia, 1999), h. 31.

${ }^{7}$ Ibid. Pendidikan di sini dapat dikatakan sebagai wujud proses yang dapat membantu pertumbuhan seluruh unsur kepribadian manusia secara seimbang ke arah positif. Pertumbuhan demikian hanya akan terjadi bila ada kesamaan konsep mengenai siapa manusia itu, bagaimana reproduksi dan keberadaannya. Sehingga ketika akan berbicara tentang pendidikan Islam, maka hal pertama yang harus dijelaskan adalah bagaimana konsep manusia menurut pandangan Islam, sebab konsep itulah yang kemudian akan dijadikan sebagai titik tolak dalam perumusan maupun pengembangan pendidikan Islam. 
Pendidikan Islam sangat berperan untuk senantiasa diaktualisasikan sehingga bisa menjadi petunjuk sesuai dengan fungsinya antara lain sebagai faktor pembimbing, pembina, pengimbang, penyaring dan pemberi arah dalam hidup menuju masyarakat yang di dalamnya tecipta persemakmuran intelektual di dalam bingkai agama. Tidak ada obat yang dapat menyembuhkan kecuali syari'at Islam itu sendiri yang di dalamnya sarat dengan petunjuk ke arah kebaikan. ${ }^{8}$ Pendidikan Islam merupakan pangkal ketaatan dan kebenaran, merupakan sarana untuk menciptakan manusia menjadi mukmin yang sempurna serta menjadikan manusia sebagai hamba Allah yang shaleh dalam seluruh segi kehidupannya. ${ }^{9}$ Pendidikan Islam yang tujuan akhirnya mengarahkan agar anak didik menjadi manusia yang bertakwa kepada Allah.

Pendidikan memang bukan sekedar transfer pengetahuan, pembinaan mental jasmani dan intelek semata, tetapi bagaimana pengetahuan dan pengalaman yang telah didapatkan dipraktekkan dalam prilaku sehari-hari. Ki Hajar Dewantara dalam hal ini menyatakan bahwa pendidikan adalah usaha yang dilakukan dengan penuh keinsyafan yang ditujukan untuk keselamatan dan kebahagiaan manusia. Pendidikan tidak hanya bersifat pelaku pembangunan tetapi sering merupakan perjuangan pula. Pendidikan berarti memelihara hidup tumbuh ke arah kemajuan, tidak boleh melanjutkan keadaan kemarin. Pendidikan adalah usaha kebudayaan, berazas peradaban, yakni memajukan hidup agar mempertinggi derajat kemanusiaan. ${ }^{10}$ Pendidikan yang islami adalah pendidikan yang mendasarkan konsepsinya pada ajaran tauhid. Dengan dasar ini maka orientasi pendidikan Islam di arahkan pada upaya mensucikan diri dan

\footnotetext{
${ }^{8}$ Ali Mahfuz, Hidāyat al-Mursyīdīn (cet. ke-4; Kairo: Al-Mațba'ah alUṡmāniyyah al-Mișriyyah, 1958), h. 69-70.

${ }^{9} \mathrm{Abū}$ al-'Ainain, Falsafah al-Tarbiyyah ..., h. 154.

${ }^{10} \mathrm{Ki}$ Hajar Dewantara, Bagian Pertama Pendidikan (Yogyakarta: Majlis Luhur Persatuan Taman Siswa, 1962), h. 19.
} 
memberikan penerangan jiwa, sehingga setiap manusia mampu meningkatkan dirinya dari tingkatan iman ke tingkat ihsan yang melandasi seluruh bentuk kerja kemanusiannya (amal saleh).

Dengan demikian pendidikan yang Islami tidak lain adalah upaya mengefektifkan aplikasi nilai-nilai agama yang dapat menimbulkan transformasi nilai dan pengetahuan secara utuh kepada manusia, masyarakat dan dunia pada umumnya. Dengan cara demikian maka seluruh aspek kehidupan manusia akan mendapatkan sentuhan nilai-nilai ilahiyah yang transcendental.

Rumusan pendidikan di atas, tampak memberikan kesan dinamis, modern, dan progresif. Pendidikan tidak boleh hanya memberikan bekal untuk membangun, tetapi seberapa jauh didikan yang diberikan itu dapat berguna untuk menunjang kemajuan suatu bangsa. Semangat progresif yang terkandung dalam pendidikan sebagaimana definisi di atas, tampak mengingatkan kita pada pesan Khalifah Umar yang mengatakan bahwa anak-anak muda masa sekarang adalah generasi di masa yang akan datang. Dunia dan kehidupan yang akan dihadapi berbeda dengan dunia yang sekarang, untuk itu apa yang akan diberikan pada anak didik harus memperlihatkan kemungkinan relevansi dan kegunaannya di masa datang. ${ }^{11}$

\section{Tantangan dan Peluang}

Pendidikan Islam masih dihadapkan pada persoalan dualisme-dikotomi antara ilmu-ilmu agama dan ilmu-ilmu umum. Selain itu, pendidikan Islam, dinilai masih belum menuntaskan konsep-konsep normatif yang berhubungan dengan cita ideal manusia yang dihasilkan. Menurut Iqbal bahwa ada tiga hal yang menyebabkan kemunduran Pendidikan umat Islam yaitu: Pertama mistisisme asketik. Kedua, hilangnya semangat induktif. Ketiga, adanya idealisasi capaian-capaian masa lampau, absolutisme

${ }^{11}$ Abudin Nata, Filsafat Pendidikan Islam (Jakarta: Logos Wacana Ilmu, 2001), h. 9-10. 
pemikir mazhab dan otoritas perundang-undangan yang mapan, telah melumpuhkan perkembangan pribadi dan menyebabkan hukum Islam praktis tidak bisa bergerak sama sekali. Oleh karena itu diperlukan reformasi dalam pendidikan Islam. ${ }^{12}$

Tantangan pendidikan Islam selanjutnya di era globalisasi ini adalah pada bidang manajemen pendidikan. Sistem manajemen pendidikan yang didasarkan pada kekeluargaan sebagaimana pada masyarakat agraris sudah tidak cocok lagi. Dalam kaitan ini paling kurang ada tiga sistem manajemen pendidikan yang relevan untuk dipergunakan sebagai berikut.

Pertama, Total Quality Management (TQM) yang berasal dari seorang ahli statistik Amerika, W. Edward Deming. Manajemen yang telah membawa kemajuan masyarakat Jepang dalam meningkatkan produktivitasnya ini berdasarkan pada teori yang menekankan pada Customer Oriented Quality dengan melihat lebih sensitif terhadap mutu yang diperoleh melalui team work yang solid dan leadership yang handal. Dalam prakteknya, manajemen ini mengharuskan adanya penilaian (akreditasi) terhadap kinerja pendidikan.

Kedua, Benchmarking Management. Manajemen ini didasarkan pada teori bahwa untuk meningkatkan mutu produksi harus didasarkan pada standarisasi mutu yang baku, sehingga tujuan produksi menjadi jelas. Dengan demikian seluruh proses produksi mengarah kepada suatu level tertentu yang sudah dirumuskan dan disepakati sebagai sebuah model.

Ketiga, School Based Management. Manajemen ini didasarkan pada teori bahwa proses pengambilan keputusan dan perumusan tujuan pendidikan yang selama ini dilakukan oleh otoritas birokrasi pusat harus didelegasikan kepada pelaksana di lapangan yaitu sekolah, sehingga efektifitas dan efisiensi

${ }^{12}$ Sayed Abdul Wahid, Thought and Reflektions of Iqbal (Lahore:Muhammad Ashraf, 1964), h. 60. 
pencapaian tujuan lebih dapat dipertanggungjawabkan. Manajemen yang terakhir ini mulai diterapkan pada lembagalembaga pendidikan non-pemerintah.

Seiring dengan perubahan paradigma pada berbagai komponen pendidikan tersebut di atas, maka sarana dan prasarana pendidikan Islam pun harus dikembangkan. Jika selama ini sarana prasarana pendidikan terbatas hanya pada gedung sekolah, maka pada era globalisasi ini berbagai sarana yang memungkinkan yang berada di luar sekolah dapat diintegrasikan dan digunakan. Khususnya mengenai sarana telekomunikasi dan informasi seperti komputer dan internet.

Salah satu kekeliruan kebijakan pendidikan Nasional yang berpengaruh secara langsung maupun tidak langsung terhadap kinerja pendidikan (educational performance) Indonesia adalah kurang diperhitungkannya lembaga pendidikan Islam dalam sistem pendidikan Nasional. Sekilas ketika kita berbicara masalah peningkatan mutu pendidikan seolah-olah semuanya ditentukan oleh sekolah. Lembaga pendidikan Islam, misalnya madrasah, pondok pesantren maupun sekolah Islam masih dipandang sebelah mata dan kurang diperhitungkan. Tidaklah mengherankan bila muncul di masyarakat stereotyping, bahwa pendidikan Islam selalu diasosiasikan dengan lembaga pendidikan terbelakang, kurang bermutu serta tidak menghasilkan lulusan (educational output) yang memadai dan tidak memiliki kemampuan komprehensif-kompetitif terutama dalam bidang ilmu pengetahuan. ${ }^{13}$

Secara sederhana bisa kita lihat dari rendahnya minat para orang tua untuk menyerahkan masa depan pendidikan anakanaknya ke madrasah atau pesantren (notabane Islam). Biasanya mereka tidak menjadikan lembaga-lembaga tersebut sebagai alternatif utama untuk menyekolahkan anak-anak mereka. Kalaupun akhirnya mereka masuk bersekolah di madrasah,

${ }^{13}$ Fahrurrozi, http://www.msi-uii.net, diakses 23 Desember 2009. 
pesantren ataupun sekolah Islam biasanya itu dilakukan karena terpaksa (karena tidak lulus di sekolah umum, misalnya). Ironi sekali, sebagai bangsa besar dengan penduduk ratusan juta jiwa dengan mayoritas penduduknya beragama Islam. Padahal menurut sebuah perhitungan manusia Muslim Indonesia adalah jumlah pemeluk agama Islam terbesar di dunia. Jika dibanding dengan negara-negara Muslim lainnya, maka penduduk Muslim Indonesia dari segi jumlah tidak ada yang menandingi. Rupaya jumlah besar (mayoritas) bukan semata-mata menjadi lembaga pendidikan Islam yang menjadi sandaran utama dalam upaya pengembangan pendidikan bermutu di Indonesia. Gambaran di atas, menunjukkan bahwa dunia pendidikan Islam di Indonesia memang begitu dilematis. Artinya di satu sisi, tuntutan untuk meningkatkan mutu dan kualitas agar dapat bersaing dengan lembaga pendidikan umum, di sisi lain perhatian dari pemerintah terhadap lembaga pendidikan Islam masih rendah bahkan masih ditempatkan bukan sebagai kelas utama (the first class) melainkan sebagai kelas kedua (the second class).

Sistem pendidikan nasional yang telah dibangun selama tiga dasawarsa terakhir ini ternyata belum mampu sepenuhnya menjawab kebutuhan dan tantangan nasional dan global dewasa ini. Program pemerataan dan peningkatan kualitas pendidikan yang selama ini merupakan fokus pembinaan masih menjadi masalah yang paling menonjol dalam dunia pendidikan kita. Jumlah angka penduduk usia pendidikan dasar yang berada di luar sistem pendidikan nasional masih menunjukkan angka yang sangat besar, sementara itu kualitas pendidikan masih jauh dari yang diharapkan. Pada sisi lain, tantangan dan perkembangan lingkungan strategis, baik nasional maupun internasional dalam berbagai bidang kehidupan semakin berat. Perkembangan ilmu pengetahuan dan teknologi, khususnya dibidang informasi, komunikasi dan transportasi yang amat cepat, eskalasi pasar bebas antar negara dan bangsa yang semakin meningkat, iklim kompetisi dalam berbagai bidang kehidupan yang semakin ketat, 
dan tuntutan demokratisasi serta masalah hak azazi manusia merupakan tantangan yang harus dijawab oleh bangsa Indonesia agar agar kita bisa hidup terus dan bertahan dalam percaturan kehidupan antar bangsa di dunia.

Pendidikan Islam sebagai subsistem pendidikan nasional. Sebagai subsistem, pendidikan Islam mempunyai tujuan khusus yang harus dicapai, dan tercapainya tujuan tersebut akan menunjang pencapaian tujuan pendidikan nasional secara keseluruhan yang menjadi suprasistennya. ${ }^{14}$ Visi pendidikan Islam tentunya sejalan dengan visi pendidikan nasional. Visi pendidikan nasional adalah mewujudkan manusia Indonesia yang takwa dan produktif sebagai anggota masyarakat Indonesia yang bhinneka. Sedangkan misi pendidikan Islam sebagai perwujudan visi tersebut adalah mewujudkan nilai-nilai keislaman di dalam pembentukan manusia Indonesia. Manusia Indonesia yang dicitacitakan adalah manusia yang saleh dan produktif. Hal ini sejalan dengan trend kehidupan abad 21, agama dan intelek akan saling bertemu. ${ }^{15}$ Dengan misi tersebut pendidikan Islam menjadi pendidikan lternatif. Apabila pendidikan yang diselenggarakan oleh atau lembaga-lembaga swasta lainnya cenderung untuk bersifat sekuler, atau memiliki ciri khas lainnya, maka pendidikan Islam ingin mengejawantakan nilai-nilai keislaman.

\section{MENATA PENDIDIKAN ISLAM DALAM PEMBERDAYAAN}

Langkah awal yang diperhatikan untuk melakukan penataan pendidikan Islam, harus dianalisis dari aspek kekuatan, kelemahan, kesempatan, dan ancaman. Pertama, pendidikan Islam (pesantren, madrasah, sekolah yang bercirikan Islam, dan perguruan tinggi) lebih dari $80 \%$ dikelola oleh swasta. Dalam pengelolaannya lebih percaya dan hormat pada ulama, percaya

\footnotetext{
${ }^{14}$ Arief Furchan, Transformasi Pendidikan Islam di Indonesia (Yogyakarta: Gema Media, 2004), h. 14.

${ }^{15}$ H.A.R. Tilaar, Membenahi Pendidikan Nasional (Jakarta: PT. Rineka Cipta, 2002), h. 159.
} 
bahwa guru mengajarkan sesuatu yang benar, panggilan agama, ibadah, ikhlas, murah, merakyat. Hal ini merupakan kekuatan (strengt) dalam pengelolaan pendidikan Islam. Kedua, kelemahan (weakness), bahwa pendidikan Islam posisinya lemah, tidak profesional hampir disemua sektor dan komponennya, stress, terombang-ambing antara jati dirinya, apakah ikut model sekolah umum atau antara ikut Diknas dan Depag. Belum ada sistem yang mantap dalam pengembangan model pendidikan agama dan pendidikan keagamaan. Ketiga, kesempatan (opportunities), bahwa dalam UU No.20 Th. 2003 memberi kesempatan atau momentum pengembangan pendidikan agama dan keagamaan. Pendidikan Islam diakui sama dengan pendidikan yang lain. Keempat, ancaman (treat), bahwa banyak lembaga pendidikan lain yang lebih tangguh dan berkualitas, Ilmu dan teknologi yang berkembang sangat pesat berlum terkejar oleh pendidikan Islam, pendidikan Islam kehilangan jati dirinya, pendidikan Islam selalu menjadi warga kelas dua, tercabut dari akar budaya komunitas muslimnya. Dalam perspektif pendidikan, mungkin akan bertanya mampukah kita menciptakan dan mengembangkan sistem pendidikan Islam yang menghasilkan lulusan-lusan yang "mampu memilih" tanpa kehilangan peluang dan jati dirinya?. ${ }^{16}$

Mutu pendidikan merupakan hal yang harus diperhatikan dan diupayakan untuk dicapai. Sebab pendidikan akan menjadi sia-sia bila mutu proses dan lulusannya rendah, tidak terbangun jiwa kemandirian dan kreatifitasnya. Lebih parah dan menyedihkan lagi jika out put pendidikannya menambah beban masyarakat, keluarga, dan negaranya. ${ }^{17}$ Saat sekarang ini, ada keinginan dari masyarakat dan berbagai lembaga pendidikan Islam untuk menjadikan pendidikan Islam sebagai salah satu pendidikan alternatif. Tetapi pemikiran ini memerlukan

\footnotetext{
1999), h. 10.

${ }^{17}$ Ahmad Baharuddin, Pendidikan Alternatif Qaryah Thayyibah (Yogyakarta: LKiS, 2007), h. 129.
}

${ }^{16}$ Mastuhu, Pemberdayakan Sistem Pendidikan Islam (Jakarta: Logos, 
paradigma baru untuk meningkatkan kualitan pendidikannya. Pertanyaannya, pendidikan Islam yang mutu dan unggul yang bagaimana? Apakah kita harus memperbaiki secara radikal terhadap kelemahankelemahan pendidikan Islam yang telah diproyeksikan oleh A. Mukti Ali, bahwa kelemahan pendidikan Islam dewasa ini, disebabkan oleh faktor penguasaan sistem dan metode, bahasa sebagai alat untuk memperkaya persepsi, dan ketajaman interpretasi (insight), kelemahan kelembagaan (organisasi), kelemahan ilmu dan teknologi. Apabila hal ini menjadi fokus, maka pendidikan Islam harus didesak untuk melakukan inovasi, tidak hanya terkait dengan kurikulum dan perangkat manajemen, tetapi juga strategi dan taktik operasional dan metodologinya. Strategi dan taktik itu, bahkan sampai menuntutperombakan model-model sampai dengan institusiinstitusinya hingga lebih efektif dan efesien dalam arti pedagogis, sosiologis dan kultural dalam menunjukkan perannya, ${ }^{18}$ untuk mewujudkan pendidikan Islam yang bermutu dan unggul.

Berdasarkan pandangan di atas, maka peran pendidikan Islam mestinya bukan hanya "dipahami dalam konteks mikro [kepentingan anak didik yang dilayani melalui proses interaksi pendidikan], melainkan juga dalam konteks makro, yaitu kepentingan masyarakat yang dalam hal ini termasuk masyarakat bangsa, negara dan bahkan juga kemanusiaan pada umumnya", sehingga pendidikan Islam integratif antara proses belajar di sekolah dengan belajar di masyarakat (learning society). Hubungan pendidikan dengan masyarakat mencakup hubungan pendidikan dengan perubahan sosial, tatanan ekonomi, politik dan negara, karena pendidikan itu terjadi di masyarakat, dengan sumber daya masyarakat, dan untuk masyarakat, maka pendidikan dituntut untuk mampu memperhitungkan dan melakukan antisipasi terhadap perkembangan sosial, ekonomi, politik dan kenegaraan secara simultan. Sedangkan, secara mikro 3.

${ }^{18}$ H.M. Arifin, Kapita Selekta Pendidikan (Jakarta: Bina Aksara, 1991), h. 
pendidikan senantiasa memperhitungkan individualitas atau karakteristik perbedaan antara individu peserta didik dalam kerangka interaksi proses belajar.

Kerangka acuan pemikiran dalam penataan dan pengembangan sistem pendidikan Islam, harus mampu mengakomodasikan berbagai pandangan secara selektif sehingga terdapat keterpaduan dalam konsep, yaitu: ${ }^{19}$ Pertama, pendidikan harus membangun prinsip kesetaraan antara sektor pendidikan dengan sektor-sektor lain. Pendidikan harus senantiasa bersamasama dengan sistem lain untuk mewujudkan cita-cita masyarakat Indonesia yang berkualitas dan kritis. Oleh karena itu, pendidikan bukan merupakan sesuatu yang eksklusif dan terpisah dari masyarakat dan sistem sosialnya, tetapi pendidikan sebagai suatu sistem terbuka dan senantiasa berinteraksi dengan masyarakat dan lingkungannya.

Kedua, pendidikan merupakan wahana pemberdayaan masyarakat dengan mengutamakan penciptaan dan pemeliharaan sumber yang berpengaruh, seperti keluarga, sekolah, media massa, dan dunia usaha.

Ketiga, prinsip pemberdayaan masyarakat dengan segenap institusi sosial yang ada di dalamnya, terutama institusi yang dilekatkan dengan fungsi mendidik generasi penerus bangsa. Seperti pesantren, keluarga, dan berbagai wadah organisasi pemuda, diberdayakan untuk dapat mengembangkan fungsi pendidikan dengan baik serta menjadi bagian yang terpadu dari pendidikan.

${ }^{19}$ Fasli Jalal, Reformasi Pendidikan dalam Konteks Otonomi Daerah (Yogyakarta: Aditia, 2001), h. 16-17. Masyarakat sangat besar peranan dan pengaruhnya terhadap perkembangan intelektual dan kepribadian individu peserta didik. Sebab keberadaan masyarakat merupakan laboratorium dan sumber makro yang penuh alternatif untuk memperkaya pelaksanaan proses pendidikan. 
Keempat, prinsip kemandirian dalam pendidikan dan prinsip pemerataan menurut warga negara secara individual maupun kolektif untuk memiliki kemampuan bersaing dan sekaligus kemampuan bekerja sama.

Kelima, dalam kondisi masyarakat pluralistik diperlukan prinsip toleransi dan konsensus. Untuk itu, pendidikan sebagai wahana pemberdayaan masyarakat dengan mengutamakan penciptaan dan pemeliharaan sumber-sumber tersebut secara dinamik.

Keenam, prinsip perencanaan pendidikan. Pendidikan selalu dituntut untuk cepat tanggap atas perubahan yang terjadi dan melakukan upaya yang tepat secara normatif sesuai dengan citacita masyarakat Indonesia baru. Pendidikan selalu bersifat progresif tidak resisten terhadap perubahan, sehingga mampu mengendalikan dan mengantisipasi arah perubahan.

Ketujuh, prinsip rekonstruksionis, bahwa kondisi masyarakat selalu menghendaki perubahan mendasar. Maka pendidikan harus mampu menghasilkan produk-produk yang dibutuhkan oleh perubahan tersebut. Paham rekonstruksionis mengkritik pandangan pragmatis sebagai suatu pandangan yang cocok untuk kondisi yang relatif stabil. Pendekatan pemecahan masalah bersifat lebih berorientasi masa kini, sedangkan pendekatan rekonstruksionis lebih berorientasi masa depan dengan tetap berpijak pada kondisi sekarang.

Kedelapan, prinsip pendidikan berorientasi pada peserta didik. Dalam memberikan pelayanan pendidikan, sifat-sifat peserta didik yang umum maupun yang spesifik harus menjadi pertimbangan. Layanan pendidikan untuk kelompok usia anak berbeda dengan remaja dan dewasa, termasuk perbedaan pelayanan bagi kelompok anak-anak berkelainan fisik dan mental termasuk pendekatan pendidikan bagi anak-anak di daerah terpencil tidak dapat disamakan dengan anak-anak di perkotaan. 
Kesembilan, prinsip pendidikan multicultural, bahwa sistem pendidikan harus memahami bahwa masyarakat yang dilayaninya bersifat plural, sehingga pluralisme harus menjadi acuan dalam mengembangkan pendidikan dan pendidikan dapat mendayagunakan perbedaan tersebut sebagai sumber dinamika yang bersifat posetif dan konstruktif.

Kesepuluh, pendidikan dengan prinsip global, artinya pendidikan harus berperan dan harus menyiapkan peserta didik dalam konstelasi masyarakat global.

Paradigma lama pendidikan Islam yang telah terbangun sejak abad pertengahan (periode Islam), dengan mengkaji dan mempelajari teks-teks keagamaan dengan metode hafalan, bersifat mekanis, mengutamakan pengkayaan materi, sudah harus ditinggalkan untuk menuju paradigma baru pendidikan. Faisal Ismail, menyatakan bahwa pendidikan dan pengajaran dalam Islam bukanlah sekedar kegiatan untuk mewariskan harta kebudayaan dari generasi terdahulu kepada generasi penggantinya yang hanya memungkinkan bersifat reseptif, pasif, menerima begitu saja. Akan tetapi pendidikan Islam harus berusaha mengembangkan dan melatih peserta didik untuk lebih bersifat direktif, mendorong agar selalu berupaya maju, kreatif dan berjiwa membangun.

Pendidikan Islam harus berorientasi kepada pembangunan dan pembaruan, pengembangan kreativitas, intelektualitas, keterampilan, kecakapan penalaran yang dilandasai dengan "keluhuran moral" dan "kepribadian", sehingga pendidikan Islam akan mampu mempertahankan relevansinya di tengah-tengah laju pembangunan dan pembaruan paradigma sekarang ini, sehigga pendidikan Islam akan melahirkan manusia yang belajar terus (long life education), mandiri, disiplin, terbuka, inovatif, mampu memecahkan dan menyelesaikan berbagai problem 
kehidupan, ${ }^{20}$ serta berdayaguna bagi kehidupan dirinya dan masyarakat.

Paradigma baru pendidikan Islam harus diorientasikan kepada pembangunan, pembaruan, pengembangan kreativitas, intelektualisme, keterampilan, kecakapan, penalaran, inovatif, mandiri, disiplin dan taat hukum, terbuka dalam masyarakat plural, dan mampu menghadapi serta menyelesaikan persoalan pada era globalisasi dengan dilandasi keanggunan moral dan akhlak dalam usaha membangun manusia dan masyarakat yang berkualitas bagi kehidupan dalam masyarakat madani Indonesia.

Dalam kajian teoretis sering diperdebatkan apakah perubahan atau dinamika dalam masyarakat merupakan perubahan budaya atau perubahan sosial. Yang pertama, berkaitan dengan perubahan yang berhubungan dengan ide-ide dan nilai-nilai yang dianut oleh kelompok masyarakat. Sedangkan yang kedua berkaitan dengan perubahan di bidang pola hubungan dalam masyarakat dan perkembangan kelembagaannya. Kedua perubahan itu mempunyai hubungan timbal baik.

Saat ini, masyarakat sudah mulai selektif dalam memilih lembaga pendidikan dari tingkat taman kanak-kanak sampai perguruan tinggi. Perubahan demikian merupakan akibat dari rangkaian perubahan yang terjadi di dalam skala mikro. Artinya, perubahan yang terjadi dalam masyarakat pada bidang lain mempengaruhi pula pandangan dan pilihan masyarakat terhadap pendidikan. Inilah yang disebut masyarakat sebagai kesatuan sistem.

Perubahan masyarakat secara berkelin dan akan mempengaruhi pilihan masyarakat terhadap pendidikan. Pendidikan yang akan dipilihnya sudah barang tentu yang dapat

${ }^{20}$ Faisal Ismail, Paradigma Kebudayaan Islam Studi Kritis dan Refleksi Historis (Yogyakarta: Tiara Ilahi Press, 1998), h. 97-98. 
mengembangkan kualitas dirinya sesuai dengan perkembangan masyarakat. Sebaliknya, pendidikan yang kurang memberikan janji masa depan tidak akan mengundang minat atau antusiasme masyarakat.

Sesuai dengan ciri masyarakat tersebut, maka pendidikan yang akan dipilih oleh masyarakat adalah pendidikan yang dapat memberikan kemampuan secara teknologis, fungsional, individual, informatif dan terbuka. Dan yang lebih penting lagi, kemampuan secara etis dan moral yang dapat dikembangkan melalui agama. Dipandang dari potensi kelembagaan yang dimilikinya, pendidikan Islam sebenarnya dapat memainkan peran-peran signifikan di tengah arus besar perubahan masyarakat. Dalam konteks ini, ketajaman visi pengelola pendidikan Islam, dalam artian wawasan pengembangan pendidikan strategis di masa depan sangat dibutuhkan.

\section{PENUTUP}

Untuk saat ini seharusnya lembaga Pendidikan Islam memerlukan adanya perencanaan strategis, dengan menyusun visi, misi, tujuan, sasaran, metode, program dan kegiatan. Hal ini dimaksudkan sebagai perencanaan jangka panjang untuk menjawab tantangan eksternal yang semakin dinamis dan kompleks. Proses seperti ini perlu melibatkan sejumlah orang yang tak kalah pentingnya dalam ikut mensukseskan Pendidikan Islam. Upaya mengikutsertakan masyarakat dalam meningkatkan mutu pendidikan dengan memberikan pertimbangan, arahan, dukungan, tenaga, sarana dan prasarana serta pengawasan pendidikan, inilah yang dimaksud penulis dengan istilah memberdayakan masyarakat. Sehingga keberhasilan pendidikan bukan saja menjadi tugas dan tanggungjawab institusi pendidikan saja tetapi yang lebih penting adalah bagaimana masyarakat dapat memberikan respon positif terhadap perkembangan pendidikan yang ada saat ini, karena out-put pendidikan pada akhirnya akan bermuara pada satu titik yaitu masyarakat. 


\section{DAFTAR PUSTAKA}

Abū al-'Ainain, Abū Khalīl, Falsafah al-Tarbiyyah al-Islāmiyyah fī alQur'ān al-Karīm, t.t.p. Dār al-Fikr al-'Arabī, 1980.

Arifin, H. M., Kapita Selekta Pendidikan, Jakarta Bina Aksara, 1991.

Baharuddin, Ahmad, Pendidikan Alternatif Qaryah Thayyibah, Yogyakarta: LKiS, 2007.

Dewantara, Ki Hajar, Bagian Pertama Pendidikan, Yogyakarta: Majlis Luhur Persatuan Taman Siswa, 1962.

Fahrurrozi, http://www.msi-uii.net,akses, diakses Sabtu, 23 Desember 2009.

Fadjar, A. Malik, Reorientasi Pendidikan Islam, Jakarta: Fajar Dunia, 1999.

Furchan, Arief, Transformasi Pendidikan Islam di Indonesia, Yogyakarta: Gema Media, 2004.

Ismail, Faisal, Paradigma Kebudayaan Islam Studi Kritis dan Refleksi Historis, Yogyakarta: Tiara Ilahi Press, 1998.

Jalal, Fasli, Reformasi Pendidikan dalam Konteks Otonomi Daerah, Yogyakarta: Aditia, 2001.

Mahfuz, Syekh Ali, Hidayat al-Musyidin, cet. ke-6; Kairo: al-Matba'at alUsmaniyyah al-Misiyyah, 1958.

Mastuhu, Pemberdayakan Sistem Pendidikan Islam, Jakarta: Logos, 1999.

Nata, Abudin, Filsafat Pendidikan Islam, Jakarta: Logos Wacana Ilmu. 2001.

Republika, Rabu, 17 Maret 2004

Sutarmadi, A., Visi dan Misi dan Langkah Strategis Pengurus DMI dan Pengelola Masjid, Jakarta: Logos, 2002.

Siradj, Said Aqil, Revitalisasi Pendidikan Islam, Republika, Rabu, 17 Maret 2004.

Shihab, M. Quraish, Membumikan al-Qur'an, Fungsi dan Peran Wahyu dalam Kehidupan Masyarakat, Bandung: Mizan, 1992.

Tilaar, H.A.R., Pendidikan, Kebudayaan, dan Masyarakat Madani Indonesia, Strategi Reformasi Pendidikan Nasional, Bandung: Remaja Rosdakarya, 1999. 
Vol. 8, No.1, Juni 2011: 81-100

Tilaar, H.A.R., Membenahi Pendidikan Nasional, Jakarta: PT. Rineka Cipta, 2002.

Wahid, Sayed Abdul, Thought and Reflektions of Iqbal, Lahore: Muhammad Ashraf, 1964. 